\title{
A Study of the Declining Status of Teacher Education in Pakistan
}

\section{Uzma Perveen ${ }^{1}$, Irshad Ahmad Farrukh ${ }^{2}$}

${ }^{1}$ Research Officer, National Accreditation Council for Teacher Education (NACTE) Pakistan

${ }^{2}$ Secretary, National Accreditation Council for Teacher Education (NACTE) Pakistan

\section{A B S T R A C T}

Quality human resource development is the major focus of all developed and developing nations of the world, and the only mean to achieve this is the education only, which needs quality teachers. It is well accepted that no system of education can be better than its teachers. It is globally accepted that teacher is the central figure in the education system of any society and it has become a near proverbial that no nation can rise above the level of its teachers. The research has also evidenced that student achievement is linked to the quality of teachers. The Education Department of the major province of Punjab has stopped the pre-service training of the teachers in all its colleges. It has recently recruited more than five thousand untrained teachers, as the department was not satisfied with the performance of its trained teachers and training procedures. It is a no denying fact that in Pakistan status and quality of teacher and teaching is gradually and continuously on the decline. This study was conducted in the existing scenario. The major objective of the study was to identify and find out the causes of decline and unsatisfactory performance of trained teachers in the historical perspective of teacher education in Pakistan. The study was qualitative in nature. A purposive sample of 20 working \& retried senior Teacher Educators and 10 senior officers of four provincial Bureaus of Education including Sindh, KPK, Baluchistan, AJK and DSD Punjab were included in the study. The sample was divided into two equal groups of 15 participants each representing each category and area. The data was collected through 12 rounds of focus group discussions of both groups with the rotation of members between groups after two meetings. The results of the study revealed the discontinuation of residential teacher training, elimination of aptitude test for admission, the involvement of private institutions in teacher education, merit-less affiliation by universities, distance mode of teacher education, Poor general education and political interference as significant factors for the decline of teachers and teaching in the country. The recommendations included mandatory aptitude test for pre-service entrance and teacher licensing, Stopping affiliation of private teacher education colleges.

KEYWORDS: untrained Teachers, Senior Teacher Educators, Bureaus of Education,

\section{INTRODUCTION}

Society needs teachers who are well prepared to face new challenges by being well equipped with social and professional skills, required in modern and technologyoriented educational society. A teacher is a highly valued personality in a society and 
teaching is considered to be the most sacred and distinctive profession. Work and worth of teachers have brought name and fame to nations. They have brought laureates to nations. The profession of a teacher has never been so challenging and demanding as it has become now. Global emphasis on literacy shows the international concern over a teacher's role in human resource development in a society. Programs have been developed to help teachers overcome the problems they face in the performance of their role in educating a society. Various programs have been launched to highlight their role in society as a role model and also help them strike a balance between performance of duties in the school and their role in society. (Hala, 2012).

A number of studies in the last 30 years have pointed out the key issues and problems of teacher education in Pakistan. There is a general consensus that quality of teachers is terribly low. A number of factors have been cited in the literature. Primary schoolteacher certification programs are relics of the 19th century normal school model.

The Quality teaching matters but not all actors in higher education consider it a priority, understand and recognize what constitutes quality teaching, or are willing and able to play a role in ensuring it takes place in their institutions. Institutions play a key role in fostering quality teaching: national regulations rarely require or prompt academics to be trained in pedagogy or to upgrade their educational competencies over their professional lifespan. Emphasis on research performance - for both institutions and individual academics - has traditionally overshadowed teaching and learning for students in many countries. Some institutional decision-making bodies might consider it almost incidental to the mission of higher education or may not have realized what their institutional policies send a message to their faculty.

\section{Objectives of the study}

The objectives of the study were to:

1. Determine the existing status of Teacher Education Programs

2. Identify the causes of declining status of Teacher Education Programs

3. Determine the significance of the wise order of decline causes

4. Recommend the remedial measures to improve the status of Teacher Education Programs 


\section{RESEARCH METHODOLOGY}

The present was of qualitative in nature. It required the analysis of opinion of the teacher educators and discussions of the focus groups.

\subsection{Population}

Generally speaking all the stakeholders and academia persons associated with teaching learning process were the basic population but for the purpose of research, those who were directly responsible for teacher preparation and associated with teacher education management comprised the population of the study. Most significant were the teacher educators and officials responsible for teacher education management and professional development of teacher educators. Therefore the actual population comprised of working and retired teacher educators and officers of Provincial Bureau of education and Directorate of staff development Punjab.

\subsection{Sample}

A purposive and convenient sample of 20 teacher educators and 10 officers from provincial bureaus of education from AJK, KPK, Sindh, Baluchistan, and Directorate of Staff Development, Punjab was selected. The first group of the sample comprised of 10 working and 10 retired teacher educators which equal number from both genders.

\begin{tabular}{|c|c|c|c|c|}
\hline \multicolumn{5}{|c|}{ Distribution of Sample of the Study } \\
\hline Gender & Provincial Bureau & Working TEs & Retired TEs & Total \\
\hline M & 7 & 5 & 5 & 17 \\
\hline F & 3 & 5 & 5 & 13 \\
\hline Total & 10 & 10 & 10 & 30 \\
\hline
\end{tabular}

Focus Group Discussion Questions

Q1: where do you place the status of Teacher Education in Pakistan today?

Q2: What is your opinion is the quality of Teacher Education in the country?

Q3: How far you are satisfied with the delivery/conduct of Teacher Education programs in private and public sector institutions?

Q4: Please make a comparison between the educational scenarios of the present Teacher Education institutions with teacher training colleges of the past. 
Q5: To what extent this general perception is true that status of Teacher Education in Pakistan is continuously on the decline: identify the causes and reasons.

Q6: What is your opinion are the most significant to less significant causes of declining status of Teacher Education?

Q7: How far you are satisfied with the existing assessment system of Teacher Education/ practicum.

Q8: To what extent the Teacher Education programs are contributing to the National Professional Standards in Pakistan.

Q9: Kindly suggest remedial measures to overcome the causes of decline to improve the Teacher Education in the country.

A brief orientation about the problem and objectives of the study was given to the participants by the research team. They were assured of the confidently of data. The sample was divided into two equal groups with 15 participants, presenting each category. Each group comprised of 5 working and 5 retired teacher educators and included 5 representatives, one from each provincial bureau and Directorate of Staff Development. Twelve rounds of focus group discussion by both groups were held to the convincing of outstation participants. The opportunity of meeting in different conferences, seminars and workshops were also availed. Four rounds of focal group discussion were combined which included

$\begin{array}{ll}\text { Initial focus group meeting } & 1 \\ \text { Transitory focus group meetings } & 2 \\ \text { Concluding focus group meeting } & 1\end{array}$

The distribution of other eight remaining focus group discussion rounds is given as under.

\begin{tabular}{|c|c|c|c|}
\hline \multicolumn{4}{|c|}{ Discussion Rounds } \\
\hline Round & Working TEs & Retired TEs & Provincial Bureau \\
\hline 1 & W1 & R1 & P1 \\
\hline 2 & W2 & R2 & P2 \\
\hline 3 & W1 & R2 & P1 \\
\hline 4 & W2 & R1 & P2 \\
\hline 5 & W1 & R2 & P2 \\
\hline 6 & W2 & R1 & P1 \\
\hline 7 & W1 & R1 & P2 \\
\hline 8 & W2 & R2 & P1 \\
\hline
\end{tabular}




\section{Data Collection}

The initial focus group meeting was infected with a brainstorming meeting wherein the group was briefed about the research problem and objectives of the study by the research team. The team shared and discussed the significance of the problem with the group and requested them to come prepared for discussion and developing questions for the forthcoming rounds of focus group discussion. The meeting lasted for about 50 minutes. The 2nd meeting was held to develop the points and questions for discussion for next rounds. Six members could not participate in this meeting for their personal reasons.

One to two questions were presented before the subgroups in each round. The group members actively participated and shared their views, questions and crossquestioning was made. The proceeding of each focus group discussion was recorded. Each round lasted for 90 to 100 minutes and was steered by senior participants. Two transitory meetings were conducted after the 4th and 8th meeting to share the data of discussion, questions/points. The summary of two transitory and eight focal group discussion round meetings was presented in the final meeting for identification of the decline causes of teacher education to concluded the results of the research.

The causes of declining status of teacher education in Pakistan were ranked in order of significance as viewed by the percentage of research participants, the sample. Less than $70 \%$ were not included in the findings. The results are presented in order of high to low level of significance.

\section{RESULTS}

The results of the study revealed

1. Elimination of aptitude test for admission to pre-service teacher education (91\%)

2. Meritless affiliation of private teacher education colleges (86.5\%)

3. Discontinuation of residential teacher training (83\%)

4. Distance mode of teacher education (83\%)

5. Poor general education $(76 \%)$

6. Political interference $(75 \%)$

\section{Recommendations}

1. Mandatory aptitude test for admission to pre-service teacher education

2. Stopping/ canceling affiliation of private teacher education colleges

3. Encouraging residential pre and in-service teacher training/education 
4. Mandatory first teacher education degree through formal mode instead of distance mode of education

5. Raising the standard of general education in the country

6. Discouraging/condemning the political interference in education

7. Initiating licensing and certification system in Pakistan

\section{REFERENCES}

Abell Foundation (2001). Teacher certification reconsidered: Stumbling for quality. Baltimore, MD: Abell Foundation.

Farooq, M. S., Husain, A. \&Mehmood, A. (2005).Comparison of the impact of activity based and traditional methods of teaching on achievement in mathematics. Bulletin of Education and Research. Lahore, University of Punjab. 27(2), 57-64.

Goldhaber, D.D., Brewer, D.J. (2000). "Does teacher certification matter? High school teacher certification status and student achievement". Educational Evaluation and Policy Analysis 22 (2), 129-145.

The government of Pakistan (1947).Report of the Pakistan National Educational Conference-1947. Karachi: Ministry of Education.

The government of Pakistan (1959). Report of the National Commission on Education-1959. Karachi: Ministry of Education.

The government of Pakistan (1972). Education Policy-1972-78. Islamabad: Ministry of Education.

The government of Pakistan (1979).National Education Policy-1979.Ministry of Education Islamabad.

The government of Pakistan (1992). National Education Policy 1992. Islamabad. Ministry of Education.

The government of Pakistan (1998).National Education Policy (1998-2010). Ministry of Education: Islamabad.

The government of Pakistan (2002). National Education Policy 2002.Ministry of Education.

The government of Pakistan (2009). National Education Policy (2009). Islamabad: Ministry of Education.

The government of Pakistan, Ministry of Education 2001, Education Sector Reforms Action Plan 2001-2004.

The government of Pakistan, Ministry of Education 2004, Education Sector Reform 2001-2 - 2005-6.

Government of Pakistan, Ministry of Education, Curriculum Wing Teacher Training Project, The B.Ed. Degree in Secondary and Elementary, 1996.

The government of Pakistan, Ministry of Education, Islamabad, The National Education Policy 19982010, 1998.

The government of Pakistan. (1947). Proceedings of Pakistan Educational Conference, 1947. Karachi: Ministry of Interior (Education Division).

The government of Pakistan. (1959). Report of the Commission on National Education. Karachi: Planning Commission

The government of Pakistan. (1979). Education Policy and Implementation Program. Islamabad: Ministry of Education

The government of Pakistan. (1998). National Education Policy 1998-2010. Islamabad: Ministry of Education.

The government of Sindh, BCEW, Jamshoro, Foreign Aided Projects and Teacher Training, 1988.

Gustafsson, J.-E. (2003). What do we know about effects of school resources on educational results? Swedish Economic Policy Review, 77-110.

Henard F, Ringuet. S (2008). The path to Quality Teaching in Higher Education, The Program Institutional Management for Higher Education (IMHE).

Henard F. (2012). Fostering quality teaching in higher education: policies and practices. Institutional management in higher education IMHE. 
Hobson, A. J. et al. (2010). International approaches to teacher selection and recruitment, OECD education working papers. No 47, OECD Publishing.

International Alliance of Leading Education Institutes (2008), Transforming Teacher Education: Redefined Professionals for 21st Century Schools. Singapore: National Institute of Education.

Jenkins, H. \& Clinton, K. (2006).Confronting the challenges of participatory culture: Media education for the 21st century. Chicago: The MacArthur Foundation.

Khan, S. H. \& Saeed, M. (2009). The effectiveness of Pre-service Teacher Education Program (B.Ed.) in Pakistan: Perceptions of Graduates and their Supervisors. Bulletin of Education and Research. Lahore, Punjab University, 31(1), 83-98.

Khan, S. H., \& Saeed, M. (2009). The effectiveness of Pre-service Teacher Education Program (B. Ed) in Pakistan: Perceptions of Graduates and their Supervisors'. Bulletin of Education and Research, 31(1), 83-98.

Memon, G., Joubish, M. F., \&Khurram, M. A. (2010). Education in Pakistan: The key issues, problems, and the new challenges. Middle-East Journal of Scientific Research, 6(6), 672677.

Musset, P. (2010). "Initial Teacher Education and Continuing Training Policies in a Comparative Perspective: Current Practices in OECD Countries and a Literature Review on Potential Effects", OECD Education Working Papers, No. 48, OECD Publishing. http://dx.doi.org/10.1787/5kmbphh7s47h-en.

Policy and Planning Wing Ministry of Education. (2009).National Professional Standards in Pakistan. Islamabad:

Quality approaches in higher education (2012). New perceptive on customer focus. American

Schwille, J., \& Dembélé, M. (2007), Global Perspective on teacher learning: improving policy and practice. Paris: UNESCO: International Institute for Educational Planning.

UNESCO. (2006).Situation analysis of teacher education in Pakistan: Towards a strategic framework for teacher education and professional development (Islamabad, UNESCO).

UNESCO. (2003). Quality of primary education in Pakistan. Islamabad: Ministry of Education. Retrieved from http://unpan1.un.org/intradoc/groups/ public/documents/APCITY/UNPAN020045.pdf

USAID, (2009). Performance gap analysis and training need assessment of teachers training institutions. Academy for educational planning, Islamabad.

Villegas-Reimers, E. (2003), Teacher professional development : an international review of literature. Paris: UNESCO.

Walsh, K. (2002). Positive spin: The evidence for traditional teacher certification, reexamined. Education Next 2 (1), 79-84.

Warwick, D. P., \&Reimers, F. (1995).Hope or Despair: Learning in Pakistan's primary schools. CT: Praeger Publisher. 